\title{
腸液內のリパーゼ賦活物啠に就いて
}

\author{
日本医科大學行德队科 磯源出
}

\section{ON THE ACTIVATOR OF LIPASE IN THE ENTRIC JUICE}

By Motoya İso

Department of Internal Medicine, Nippon Medical School, Tokyo.

(Prof. K. Gyotoku)

(1)

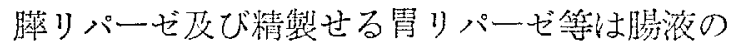
少星添加によりて扰だしく賦活され㧧力となる禁

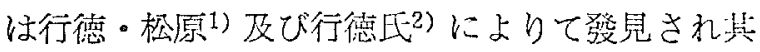
間に存する微妙なる现象，或は絸化についても可 なり詳細に街ざられている。しかしながら留活現

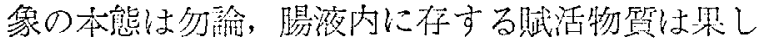
て如何なる\&の办等については全く知られる祈が ない，吾人はこの腸液内の賦活物既の本態につい て知らんと努めたのであるが，其の策は容是なら

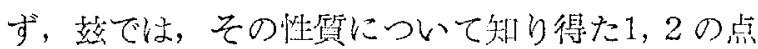
について煛吕し庭い。

\section{(2)}

朊苳によつて賦活されるリパーゼは今の北膵及 び霄の多のに限る棈であるが，後渚はそ礼を精製 するか，或惊多少の處犆を加える必贸がある。そ

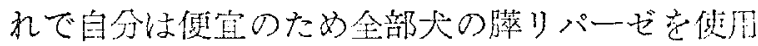

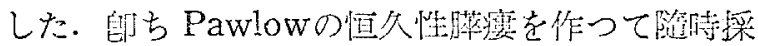
取した膵液を使用し，又腸液は犬にThiry-Vella の腸瘦を造誏して他の消化液を混ぜざる腸液を用 いた、リパーゼの䇥㫮には以前から本教室で使用 して居るトリブナリンを缃いての Tropp-pipette 法によつた。

\section{(3)}

腸液によるりパーゼの賦活作用には筸通兩液を

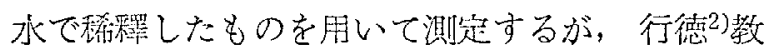

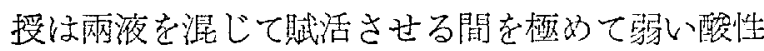

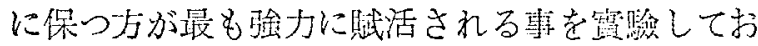

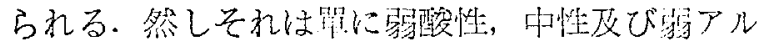
カリ性の歌段に凅别して测定しただけであるの

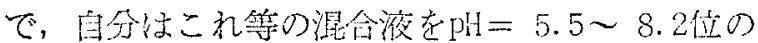

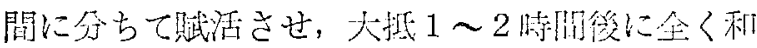

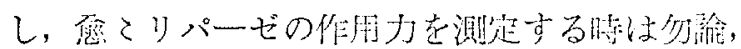

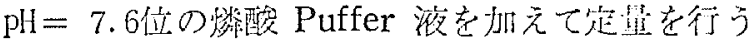
具は普通一般の通りに行なつた。

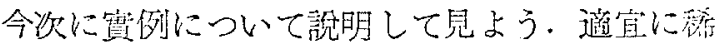
釋した嗒リパーゼ液 $100 \mathrm{cc}$ を 5 等分し其のおのお

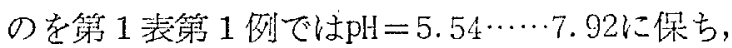

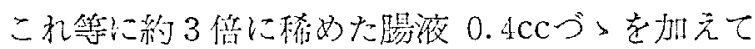

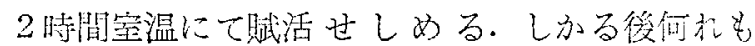
N/4アンモニア液又は酯酸液にて中稩し此の 5 本

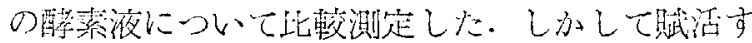

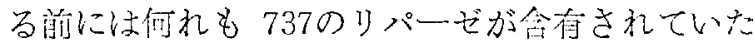

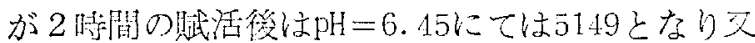
$\mathrm{pH}=7.02 に て は 3946$ となり其他の酸度にては何れ

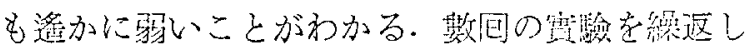

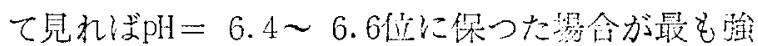
く賦活されることを知つた。少なくと吅性を境 界線として觀祭すればアルカリ性の侧よりも酸性

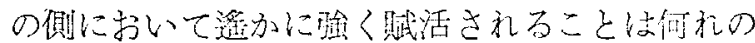

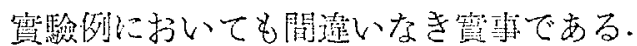

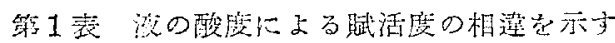

\begin{tabular}{|c|c|c|c|}
\hline & \multirow{2}{*}{ 賦活液の $\mathrm{pH}$} & \multicolumn{2}{|c|}{ リパーゼ作夙力 } \\
\hline & & 陚 活 前 & 賦泟後 \\
\hline \multirow{5}{*}{ 第 1 例 } & 5.54 & 737 & 3625 \\
\hline & 6.45 & "y & 5149 \\
\hline & 7.02 & "s & 3946 \\
\hline & 7.41 & " & 2414 \\
\hline & 7.92 & "y & 1323 \\
\hline \multirow{5}{*}{ 第 2 例 } & 5.60 & 524 & 4988 \\
\hline & 6.54 & 11 & 7233 \\
\hline & 7.05 & " & 5044 \\
\hline & 7.55 & " & 3940 \\
\hline & 8.08 & $"$ & 2257 \\
\hline
\end{tabular}


(4)

皘液を水を以て $2 \sim 3$ 倍に稀釋し之にカオリ ンの適宜量を加うればリパーゼを賦活する物質は これに吸着される事を知つたが，此の兩者の量的 關棌によりて吸着される度合に大小あるは勿綸, 陽液の濃原なるものと見掛上でも稀薄なるものの 間にも，亦多少の相逴あるは當然である. 多く の場合腸液量 (cc) と同じ位のカオリン量 ( $\mathrm{g}$ ) とを加えて混和すれば大低大部分の賦活物質は吸 着されるが，それより少量のカオリンを用いた場 合には㗪着不十分で司, 液中にも可成りの量が殘 留する場合が多い，即ち假に $5 \mathrm{cc}$ 腸夜に $5 \mathrm{~g}$ の カオリンを混和したる後十分遠心沈澱すれば其の 上清中には賦活物質を大量には証明されないが，

$3.5 \mathrm{~g}$ 位のカオリンを加えた場合には其の上清液 には可なり強力な賦活現象を認める事分出來る. 及, 反對に $7 \mathrm{~g}$ 位のカオリンを加えた際の上清中 には殆ど全く賦活物質を証明出來ない位である。 しかし䁑液には賦活物質を大量に証明する場合と 極めて少量含有する場合とがあるので，此の量的 關䋆は必ずしも記載した通りには行办ない。

カオリンに吸着させた此の賦活物質は $\mathrm{N} / 40$ ア ンモニア液を加えてよく混合し，後に遠心沈澱す れば再び取り出せるものでこれを同じく N/40 醋 酸液で中和し，これを膵リパーゼと合わせれば腸 液の原液同裳, 著明な䟼活現像を証明するもので ある(實數は省略す).トリプシノーダンを賦活す る腸活济と吾人が証明している此のリパーゼの賦 活物質とは極めて類似の性質を有して方るので最 初は兩者同一物質ではないかと思つたが必ずしも 左檬でもない樣である.

田仲氏1)は熱に對する抵抗の大小によつて兩者 を區別し $80^{\circ} \mathrm{C} 30$ 分加温すれば腸活素は其の作用 を㱠ど消失するに反し、リパーゼを䟼活するもの 法, 殘留して其の作用を現わしているが，此の 吸着現象から見ても兩者間に相當の相違を認める 樣である. 其の 1 例を舉ぐれば腸液 3 ccにカオリ ン $2 \mathrm{~g}$ の割に加うれば, (實際は少し稀釋して試驗 す）リパーゼを賦活する物質の大部分はこれに吸 着されるが，トリプシンの際の腸活素は殆ど大部 分が，向液中に殘つて吸着される部分は極めて少
ない榇である・此の吸着されるものの量的關係か ら兩者を別物なりと云い得るか否加多少疑問の 余地もあるが，しかし此の實驗から見ても兩者同 一物質なりとは考元難い樣に思われる。

斯くの如く腸液内のリパーゼ Aktivatorをカオ リンに吸着せしめ, しかる後, 再び稀きアンモニ ア液にて分離取り出したものは可なりに純䅴にな れる精製品と考えてよからう。何となればかの活 藏なる腸液からカオリンが吸着する物質は或る一 部分のものに限らるべく尚種々なるものは腸液内 に殘るであろう．而して更に此のカオリンから稀 きアンモニア液を以て浸出する時には多少殘留し て浸出されざるものが殘る等だから此の方法で得 たる Aktivatorは䅐に相當精製されたものと推定 する事が出來よう。此の一部精製された品を以て 賦活させれば次いで起るリパーゼの急速なる破墥 減弱作用が無くなるのではないかと想像したが， 其の㑯向は見られない㨾である。

(5)

既に行德教授の報告にもある樣に膵りパーゼの 陳旧なものでは晹液添加によつても作用増進を見 る事が出來ない，それが如何なる理由によるもの か不明であるが，リパーゼより何か觸手樣のもの が出ていてこれが腸液内にある Aktivator と結 合する樣な關係であるものか，而してこれが陳旧 となると共に此の所謂觸手が結合する能力を失う か， 又は䪅手そのものが脱落でもするものか，東 に角，此の閣係は極めて䊖正である、全く同樣の 關孫は膵液中のトリプジノーダンを腸夜を以て賦 活する祭にも經驗する事が出來る. 而してこれは 膵液の陳旧なるものに限らず腸液が陳旧なれば膵 液は新鮮であっても, 失張り賦活現象は証明する 事が出來ない。これに似た現䙳は胆汁を以て膵り パーゼを賦活する際にも亦見る事が出來る.

自分は此の腸夜を以てリパーゼ及びトリブシノ 一ゲンを賦活させる事實から此の兩酵素のAktivatorが同一物であるとか, 或は異なれるものであ ると加云う確証がつかないものかと考えて見た。 そしていろいろ實驗を重枚て見たが室温 $25 〜 31^{\circ} \mathrm{C}$ 


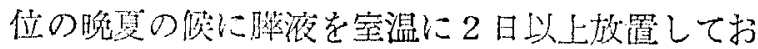
けば腸液は新鮮なものを用いてもトリプシンを賦 活する能力が失われるに区し、リパーゼを賦活す る能力は倚よく殘つているのを知つた， 区举に腸 液を同㳟室温に保存して陳旧ならしめれば胨液は 新鮮なものを用いても，知涱り賦活现象は見られ なくなるものであるが，これもリパーゼの賦活作 用が後まで殘つておるものである，即ち荤リパー ゼも腸液内の Aktivator もトリブシンに對する ものよりもリパーゼに對するものが抵抗力が強い と云う加保存し得る期間が辰いと云う事が出來よ う.これも兩者扔の㧍の異なれる物望であると云 えるか否か廏かに確言し難いが，しかし兩者同一 物質であるとは少し云い難い嵄である.

\section{(6)}

腸液中の賦活物質の性質については吾人の上記

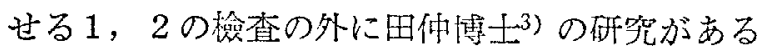
位で未だ㱠ど知らる〉所がないここれがカオリン を以て吸着される所を見れば，琶らく蛋白質か或 は蛋白筫と近い關係にあるものではあるまいか。 從つて熟によつて相賞程度の揁害を㭬るものと考

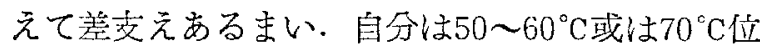
の水浴中にて30〜50分加温すればリパーゼの賦活 作用が或程度の減弱を蒙るであろうと予想して筧 驗を繰返したが其の傾は除り芫られなかつた。し かし更に80〜90 $\mathrm{C}$ 或はそれ以上の高温を用うれば 最初は賦活现象の減弱が現われる親に思われたが 實驗を繰返す中に上記の關係が起だ不明瞭に現わ れる事を知つた。

今䆩例を示して說明して見よう。師ち腸液 $3 \mathrm{cc}$ に水を加えて10ccとなしこれにカオリン $2 \mathrm{~g} を$ えて十分混和したる後, 完全に遠心沈洪したもの を4分し，1本はその䧳とし，他の 3 本は $65^{\circ} \mathrm{C}$ ， $75^{\circ} \mathrm{C}$ 及び $85^{\circ} \mathrm{C}$ の水浴中におのおの30分間保ち, 此 の4者について䟼活する程度を測定して見た，其 の結果は第 2 表に示す樣に 1 時閪後の測定では, 加熱しない腸液を用いたものは膵りパーゼを 6.4 倍に賦活したが，喠々なる温度に加熱した他の3 つの腸液を加えたものは賦活度が明汃に低いので

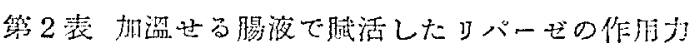

\begin{tabular}{|c|c|c|}
\hline & \multicolumn{2}{|c|}{ リパーゼ置 } \\
\hline & 趾活後 1 時間 & 賦活後 2 時間 \\
\hline$P$ & 538 & 538 \\
\hline $\mathrm{P}+\mathrm{D}_{65}$ & 3055 & 4050 \\
\hline$P+D_{75}$ & 1733 & 3974 \\
\hline $\mathrm{P}+\mathrm{D}_{35}$ & 1460 & 4084 \\
\hline$P+D$ & 3450 & 2063 \\
\hline
\end{tabular}

Dは其のまつの晹液

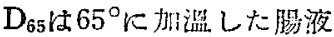

$\mathrm{P}$ は蕬液

恐らく腸液が非活性になつた當然の結果だと思つ た。しかし 3 時間後に再び測定した結果は表の如 く加温した腸液を加えたものは何れも 1 時間值よ りも却って大となつている．生の腸液を其のま 〉加えたものは當然減弱している、最初は何の意

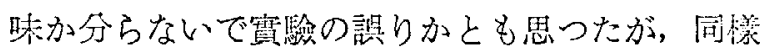
の賽瞼を繰返せば多少の例外はあるにもさよ大來 数似の成績索得た，又賦活時間を10時間导15時間 も取つても普通の如く酵素力の減弱を余り來たさ ない，郎ち腥液を添加してリパーゼを賦活する祭 には陽液の性質如何によつて賦活度も，又其の時 間的關係も一定してはいないが初改 1〜2跱䦌以 内には數培乃至數千倍に堌蛀されるが其後は急速 に破溒されて作用が減弱されるので，一旦賦活さ れたリパーゼ液を以てしては定量法を繰还して定 まれる値を得ることは不可能だと云う事は, 幾度 も經驗もし記載もしている所であるが，しかし表 記の樟な成績が事實とすればこれを說明し得る研

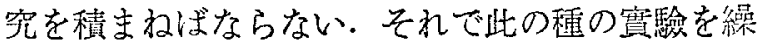
返し行なつて見たが，腸液を $90^{\circ} \mathrm{C}$ 前後の水浴にて 30分間加温すれば，加温せざる正常の腸液よりも 初めは膵りパーゼを賦活する能力が冴いが，混合 して數時間經つと共に舞々作用力高まり減弱する 事がない。これに反し普通の晹液を用いて賦活し た際には、兩液を混合して1〜2時を經ればリパ 一ゼ作用力は最高に暹し，其後は急速に破壞され て作用力急減する事は稂に繰返し記戴した處であ る.更に一例を㦛げて說明を加えてみよう。 
䁑液を水にて約 3 倍半に稀釋しこれを 2 分し

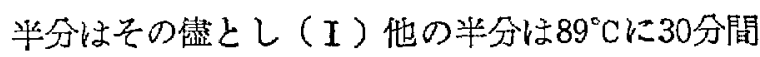
加温す（II）. 又膆液を 85 倍にうす以上記 2 種の 啺夜を以て賦活作用の程度を檢査した，その成續

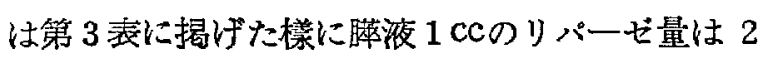
93單位で翌日まで攀る所がないのは當然である。

これに晋通の晹液を加えて䟼活したものは 2 時間 後において,2482單位と云う最高量を示すが, 既に 3 時間半後においては1635䑩位に減少し柆日は著 しく弱まり516單位となつている.これに反し89 ${ }^{\circ} \mathrm{C} に$ 加温した腸液を用いて賦活した場合は 1 時間 後には988單位となり，明かに賦活されはするが， 加温されざる腸液を用いた場合よりも甚だしく微 弱である、しかし 3 時間以後になれば普通の腸夜 を使用したものでは濑次に，而も急速に，醭素の 破壤を証明するが，加温せる啺液を以て賦活した ものは混合後 3 時間半にして2896單位となり, 其 のま〉持續して一書夜位の間なれば酵素の破壇を 來たす事がない。

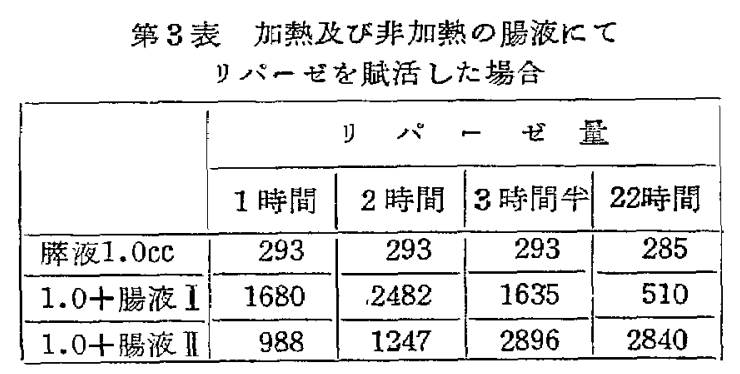

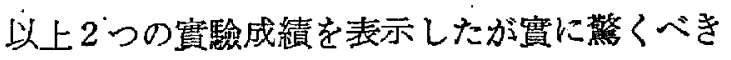
事實と云わ杖ばなない，而して腸液を加温する

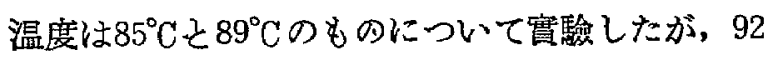
$\sim 3{ }^{\circ} \mathrm{C}$ 高温でも多少の相違は認められるにして も大佮は類似の成䋶を得るものである. $90^{\circ} \mathrm{C}$ 前 後と云えば，腸液を 30 分も加温すれば蛋白質の 凝固する結果であろうが, 明かに白色の混濁を生 ずるもので, 從つて腸液に相當の變質を來たす事 は想像に難くない. 自分の最初の予想は此の加温 によつてリパーゼの賦活作用は當然減弱するであ ろうと思った. 若し $6 \sim 70^{\circ} \mathrm{C}$ の加温で作用減弱が 認められなけれぱ更に高温にては何時かは作用減
弱する点があるに相違ないと思つた。而して實測 の結果も膵液に此の加温した腸液を加えた後の初 めの項は余り賦活現象は現われないので, 吾人の 予想が的中したのであろうと思つた. しかし混合 後10時間以上を經て再び測定したが, 初めに定量 したものよりも遥加に強力な作用力を証明したの で，更に實驗を繰返し此の事實に諆りなき事を知 つたので其の意義を者察するに至つたものであ る.

腸液によるリパーゼの賦活現像が如何なる機序 によつて惹起されるか性末だ明かではない。しか し一面リパーゼが賦活蜰力となると共に他面, こ れが急速に破㙥減弱する現象も起こつているもの で此の兩者は離るべからざる關係にあるものと考 えていた。しかし今度の實驗成續少ら考えて見れ ば晹夜内にはリパーゼを䟼活強力となす物䝷があ ると同時に他面，賦活されたりバーゼを破壞減弱 せしめる他の物質をも含有しているものの樣に思 われる。即ちこれ迄腸液による膵リパーゼの賦活

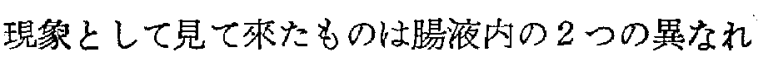
る物䫓によつて惹起されていた事を知る事が出來 た。而して其の前者, 師亏賦活強力となす物質は 加温によつて其の作用を幾分緩慢に現わす事は諗 わられるが，しかし余り强くは障害されない樣で あるが，後者師ちリパーゼを破壤減弱せしめる物 質は此の加温によりて強く害されるため，一旦强 まつたリパーゼも其後容易に減弱しないものであ ろう.

此の事實は極めて重要なる發見で從來は腸液を 以て一度賦活すれば最初は強力となるが，其後は 急速に作用力減弱して止まる所が多いので實驗を 繰返し行なつて，確實を期する事も出來ないし， 或は此のリパーや液を用いて種々なる比較研究も 出來なかつたが, 此の試驗の樣に腸液を $90^{\circ} \mathrm{C}$ 前後 に加温して賦活したるものは他の消化酵素液と同 樣, これを原液として貯藏して繰返し實驗を重ね 得られるに至つたので研究者に非常な便益を與え るに至つた譯である。 


\section{(7) 結 論}

（1）腸液を以てリパ一ゼを賦活するには其の メジウムを $\mathrm{pH}=6.5$ 前後の驹酸性に保ちて行えば 最も急遗に最高値に迕するものである。

（2）トリプシノーゲンを賦活する䭪活新とリ パーゼを賦活する腸液内の物質とは極めて類似し て區別し奞いが，カオリンを以て吸着する試践で はその程度に大小を諗为られる樣である．印ちり パーゼの賦活物質は比較的容易に吸着されるに反 し陽活续は吸着される程度が多少小である。

（3） 2 〜 3 日宝温に保てる䐙液を腸液を以て 賦活する際トリプシンは佮, 賦活されるがリパー ゼは既に賦活されない，反對に古い晹液を用いて 賦活現象を檢する際にも同樣でリパーゼの方が賦 活され難い，邲ち兩酵素の Aktivatorは同一物で はないように思われる。
（4）腸夜を $90^{\circ} \mathrm{C}$ 前後に加温すれば初めリパー ゼ表賦活する性質は弱まるが，時間經ちたる後で は強力に賦活された結果となつている，且つ普通 は其後に見られる作用力の減弱を來たすが，此の

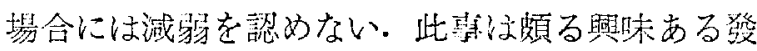
見であつて，著者は從來見ていた腈液内の賦活物 翼を二つのものから成つていると考えた。四方，

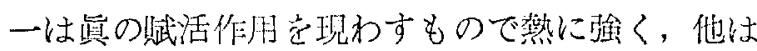
一旦䟼活されたリパーゼを破塆減弱せしめるもの で，90 C 前後の熱で大体無力となるものであるう.

\section{主要文献}

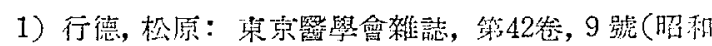
3 年). -2) 行德：日本照大槁, 第 2 卷, 第 6 號(炤和

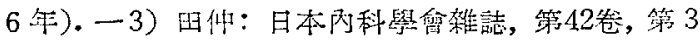
䟷(昭租28年).

[涭稿・昭和30年 9 月 8 日] 